\title{
FDS Simulation High Rise Building Model for Unity 3D Game Engine
}

\author{
Yongzhe $\mathrm{Xu}^{1}$, Eunju $\mathrm{Kim}^{1}$, Kyunjoo Lee ${ }^{2}$, Jaesug $\mathrm{Ki}^{1, *}$ and Byungsoo Lee ${ }^{1, *}$ \\ ${ }^{1}$ Department of Computer Engineering, Universty of Incheon, Korea \\ 2MaxOn Soft, Co., Ltd, Korea \\ yongzhexu@hotmail.com,lisun@maxonsoft.com, leebone28@hanmail.net, \\ \{skyblueki,bsl\}@incheon.ac.kr
}

\begin{abstract}
Smoke simulation is an interesting topic in simulation fluid dynamics and graphics area. Stack Effect Fire model was happened in fire of High Rise building. Simulation this fire model and smoke scene is one of the most challenging tasks in fluid dynamics of computer graphics area. In this paper proposed Smoke simulation rendering is based on game engine of particle system. But common game engine don't have stack effect model and compute coordinate position algorithm. Recently proposed method based on FDS's (Fire Dynamic Simulation) result Excel file which improves Unity 3D game engine for stake effective fire model and smoke boundaries. Using Excel file coordinates to improve Unity $3 D$ game engine particle system, and changes the original game engine particle system, over the coordinates of particles moving location, boundary and fire model stake effect look like real world fire model. Recently game engine computer graphic researcher usually control computing resources focused on smoke visualization skip fire effect and physically problem. In this paper, need focused on smoke location boundary and fire model stake effect. The proposed method can change smoke and fire model of stack effect and particles more accurately and efficiently than other, rendering is implemented by making smoke particles and physically effect. After putting the coordinate form FDS into Unity3D game engine Experiment performance result shows particles more look like reality, and gives neutrality and reality to user's view. This algorithm problem is from simulation high rise building mesh with loading time need more computer resource, and need to change some effect in Unity $3 D$ game asset.
\end{abstract}

Keywords: Computer Graphics, Fire Dynamics Simulator (FDS), Smoke, Particle System, Fluid Dynamics, Unity 3D, Fire Simulation

\section{Introduction}

With the development of modern industry, more and more people are flowing into big cities. Accordingly, the housing problem in big cities is becoming more and more serious. Housing problem is big problem in this time. Modernization and urbanization bring both benefits and problems. In order to solve the problem of housing, high rise building have been and are being put up in ever greater numbers in more and more big cities. High rise building have their advantages and also have dis advantages, in urban areas where land is very expensive but human need that land, they take up less space. That high rise building can give a city striking beauty. But high rise building may be dangerous when fire accident happened in building. Recently there has been a remarkable growth of fire 
accidents, and almost every day can see fire engines rushing through streets. Fires have not only resulted in heavy economic losses but also injured and killed many people. Fires Simulation high rise building presents a major challenge to the fire research community. Fires in high rise building impose more physical demands on a fire department than a common fire in lower building. The fire floor maybe impossible during the early stages of the fire due to the inaccessibility of elevators and stairwells, or due to the prolonged the survivor of evacuation. High rise building fire primary responsibility is to save survivor life and fire fighters cannot be expected to promptly control fires in building where the upper floors above reach of their equipment [1]. From this simulation or game engine, FDS requires a great amount of time to simulate real-world fire model of stack effect and smoke boundary. Result system performance less than common particle system. But Working with real time simulation of physically of fire model stack effect and find dynamics simulation of 3D fluid solver is this paper main goal.

\section{Related Works}

USA NIST and NFPA Manuel about fire protection "High Rise Building Fires” In 2005-2009, an estimated 15,700 reported high-rise structure fires per year resulted in associated losses of 53 civilian deaths, 546 civilian injuries, and \$235 million in direct property damage per year. An estimated 2.6\% of all 2005-2009 reported structure fires were in high-rise buildings. The trends in high-rise fires and associated losses (inflationadjusted for property damage) are clearly down, but the sharp post-1998 reduction appears to be mostly due to the change to NFIRS Version 5.0, which is shifting estimates to lower levels that also appear to be more accurate.

Four property classes account for roughly half of high-rise fires: apartments, hotels, facilities that care for the sick, and offices. In 2005-2009, in these four property classes combined, there were 7,800 reported high-rise structure fires per year and associated losses of 30 civilian deaths, 352 civilian injuries, and \$99 million in direct property damage per year. The property damage average is inflated by the influence of one 2008 hotel fire, whose $\$ 100$ million loss projected to nearly $\$ 40$ million a year in the analysis. Most high-rise building fires begin on floors no higher than the 6th story. The fraction of 2005-2009 high-rise fires that began on the 7th floor or higher was 32\% for apartments, $22 \%$ for hotels and motels, $21 \%$ for facilities that care for the sick, and $39 \%$ for office buildings. The risk of a fire start is greater on the lower floors for apartments, hotels and motels, and facilities that care for the sick, but greater on the upper floors for office buildings.

High-rise apartments have a slightly larger share of their fires originating in means of egress than do their shorter counterparts ( $4 \%$ vs. $3 \%$ ). The same is true of hotels (7\% vs $5 \%$ ) and facilities that care for the sick (6\% vs. $4 \%$ ). In offices (4\% vs. $6 \%$ ), the differences in percentages are in the opposite direction, which means that high-rise buildings in those properties have a smaller share of their fires originating in means of egress. In all four property classes, the differences are so small that one can say there is no evidence that high-rise buildings have a bigger problem with fires starting in means of egress [2].

From Table 1 discuss high-rise building fire from 1989 2009. Other section has more detail data about high rise building fire accident. Analysis of 2005-2009 fires is done separately for fires reported as confined fires - confined to fuel burner or boiler, cooking vessel, chimney or flue, trash, incinerator, or commercial compactor. These are fires reported to U.S. municipal fire departments and so exclude fires reported only to Federal or state agencies or industrial fire brigades. Estimates include proportional share of fires with unknown building height (until 1998) or number of stories above ground coded as unknown, blank or zero (from 1999 on). Fires are rounded to the nearest hundred, civilian deaths to the nearest one, civilian injuries are rounded to the nearest ten, and direct 
property damage to the nearest million dollars. Property damage has been adjusted for inflation, using the Consumer Price Index, to 2009 m dollars

Table 1. High Rise Building Fires in Selected Property Classes, by Year

\begin{tabular}{|c|c|c|c|c|c|}
\hline Year & Fires & $\begin{array}{l}\text { Civilian } \\
\text { deaths }\end{array}$ & $\begin{array}{l}\text { Civilian } \\
\text { Injuries }\end{array}$ & $\begin{array}{c}\text { Direct Damage as } \\
\text { report } \\
\text { (in millions) }\end{array}$ & $\begin{array}{l}2009 \text { dollars } \\
\text { (in millions) }\end{array}$ \\
\hline 1985 & 17,200 & 66 & 670 & $\$ 25$ & $\$ 51$ \\
\hline 1986 & 15,100 & 38 & 550 & $\$ 41$ & $\$ 81$ \\
\hline 1987 & 13000 & 52 & 640 & $\$ 36$ & $\$ 68$ \\
\hline 1988 & 14,600 & 94 & 780 & $\$ 104$ & $\$ 188$ \\
\hline 1989 & 14,800 & 111 & 800 & $\$ 58$ & $\$ 100$ \\
\hline 1990 & 13,300 & 84 & 620 & $\$ 47$ & $\$ 78$ \\
\hline 1991 & 13,100 & 23 & 750 & $\$ 150$ & $\$ 237$ \\
\hline 1992 & 13,600 & 35 & 830 & $\$ 83$ & $\$ 127$ \\
\hline 1993 & 12,400 & 43 & 700 & $\$ 60$ & $\$ 89$ \\
\hline 1994 & 11,400 & 57 & 950 & $\$ 60$ & $\$ 87$ \\
\hline 1995 & 10,000 & 55 & 690 & $\$ 44$ & $\$ 62$ \\
\hline 1996 & 12,100 & 64 & 790 & $\$ 69$ & $\$ 94$ \\
\hline 1997 & 11,400 & 33 & 560 & $\$ 43$ & $\$ 58$ \\
\hline 1998 & 10,000 & 37 & 680 & $\$ 42$ & $\$ 56$ \\
\hline 2005-2009 & 7800 & 30 & 350 & \$99* & $\$ 99$ \\
\hline
\end{tabular}

* Average damages in 2005-2009 are greatly inflated due to one 2008 fire in a 32-story building, with damages of $\$ 100$ million, which projected to nearly $\$ 40$ million a year. Source: NFIRS and NFPA survey

\subsection{What is High-rise Building and Different common Building?}

American Fire-Rescue International FRI 2010 maintained high-rise building is which is more than 6 floor tall or where the highest floor intended for regular occupancy is 75 feet. High rise building fire is hard to fire suppression and building window is hard break too[15].

\subsection{Why Research on this Tropic?}

Why research on this tropic? Because when fire in high rise building only 10 15\% human behavior remain calm and act quickly and efficiently, 15\% human descend into a hysteria other human do nothing or fall in confusion, be freezing. Why human don't know effective way to escape? The world trade center accident only $45 \%$ survivors knew the building had 3 stairwells only 50\% know the rooftop doors would be locked [19].

\subsection{The Driving Force for the Stack Effect}

There is a pressure difference between the outside air and the air inside the building caused by the difference in temperature between the outside air and the inside air [18]. That pressure difference ( $\Delta \mathrm{P})$ is the driving force for the stack effect and it can be calculated with the equations presented below. The equations apply only to buildings where air is both inside and outside the buildings. For buildings with one or two floors, $\boldsymbol{h}$ is the height of the building. For multi-floor, high-rise buildings, $\boldsymbol{h}$ is the distance from the openings at the neutral pressure level (NPL) of the building to either the topmost openings or the lowest openings. The NPL affects the stack effect in high-rise buildings. For flue gas stacks and chimneys, where air is on the outside and combustion flue gases are on the inside, the equations will only provide an approximation and $\boldsymbol{h}$ is the height of the flue gas stack or chimney. $\Delta \mathrm{P}=$ available pressure difference, in $\mathrm{Pa}, \mathrm{C}=0.0342, \mathrm{a}=$ 
atmospheric pressure, in $\mathrm{Pa}, \mathrm{h}=$ height or distance, in $\mathrm{m}$, To $=$ absolute outside temperature, in $\mathrm{K}, \mathrm{Ti}=$ absolute inside temperature, in $\mathrm{K}$

$$
\Delta P=\operatorname{Cah}\left(\frac{1}{T_{o}}-\frac{1}{T_{i}}\right)
$$

The draft (draught in British English) flow rate induced by the stack effect can be calculated with the equation presented below. The equation applies only to buildings where air is both inside and outside the buildings. For buildings with one or two floors, $h$ is the height of the building and $\mathrm{A}$ is the flow area of the openings. For multi-floor, highrise buildings, $A$ is the flow area of the openings and $h$ is the distance from the openings at the neutral pressure level (NPL) of the building to either the topmost openings or the lowest openings. The "NPL affects the stack effect in high-rise buildings". For flue gas stacks or chimneys [6], where air is on the outside and combustion flue gases are on the inside, the equation will only provide an approximation. Also, A is the cross-sectional flow area and $\mathrm{h}$ is the height of the flue gas stack or chimney. $\mathrm{Q}=$ stack effect draft (draught in British English) flow rate, $\mathrm{m}^{3} / \mathrm{s}, \mathrm{A}=$ flow area, $\mathrm{m}^{2}, \mathrm{C}=$ discharge coefficient (usually taken to be from 0.65 to 0.70 ), $\mathrm{g}=$ gravitational acceleration, 9.81 $\mathrm{m} / \mathrm{s}^{2}, \mathrm{~h}=$ height or distance, $\mathrm{m}, \mathrm{Ti}=$ average inside temperature, $\mathrm{K}$ To = outside air temperature, $\mathrm{K}$.

$$
Q=C A \sqrt{2 g h \frac{T_{i}-T_{o}}{T_{i}}}
$$

\subsubsection{Global High Rise Building Research}

American: high rise building fire list

Citied in "HIGH RISE BUILDING FIRES" is Table 2 American high rise building fire list. Recently USA government training firefighter based on Crisis game engine. In this paper using Unity 3D game engine to simulation this high rise building fire model part. Crisis game engine is very powerful and amazing engine. But in multiply game engine need more programming and DB resource [13] and that engine hard to study and too expensive. Also the game engine need more computing resource need good graphic card to running it.

Table 2. American High Rise Building Fire List

\begin{tabular}{|c|c|c|c|c|}
\hline Building & Location & Date & Death(s) & Notes \\
\hline Asch Building & $\begin{array}{c}\text { New York } \\
\text { City }\end{array}$ & March 25, 1911 & 146 & $\begin{array}{c}\text { Triangle Shirtwaist Factory } \\
\text { fire }\end{array}$ \\
\hline $\begin{array}{c}\text { Empire State } \\
\text { Building }\end{array}$ & $\begin{array}{c}\text { New York } \\
\text { City }\end{array}$ & July 28, 1945 & 14 & Plane crash \\
\hline 40 Wall Street & $\begin{array}{c}\text { New York } \\
\text { City }\end{array}$ & May 20, 1946 & 5 & Plane crash \\
\hline
\end{tabular}




\begin{tabular}{|c|c|c|c|c|}
\hline Building & Location & Date & Death(s) & Notes \\
\hline $\begin{array}{l}\text { Winecoff } \\
\text { Hotel }\end{array}$ & Atlanta & December 7, 1946 & 119 & $\begin{array}{l}\text { Deadliest hotel fire in U.S. } \\
\text { history }\end{array}$ \\
\hline $\begin{array}{l}1 \text { New York } \\
\text { Plaza }\end{array}$ & $\begin{array}{l}\text { New York } \\
\text { City }\end{array}$ & August 5, 1970 & 2 & \\
\hline Rault Tower & New Orleans & November 29, 1972 & 6 & \\
\hline $\begin{array}{l}\text { One World } \\
\text { Trade Center }\end{array}$ & $\begin{array}{l}\text { New York } \\
\text { City }\end{array}$ & February 13, 1975 & 0 & \\
\hline $\begin{array}{l}\text { MGM Grand } \\
\text { Hotel }\end{array}$ & Las Vegas & November 21, 1980 & 84 & $\begin{array}{c}\text { Main article: } M G M \text { Grand } \\
\text { fire }\end{array}$ \\
\hline $\begin{array}{l}\text { Las Vegas } \\
\text { Hilton }\end{array}$ & Las Vegas & February 10, 1981 & 8 & Arson \\
\hline $\begin{array}{l}\text { First Interstate } \\
\text { Tower }\end{array}$ & Los Angeles & May 4, 1988 & 1 & $\begin{array}{c}\text { Main article: First Interstate } \\
\text { Tower fire }\end{array}$ \\
\hline $\begin{array}{l}\text { One Meridian } \\
\text { Plaza }\end{array}$ & Philadelphia & $\begin{array}{c}\text { February 23-24, } \\
1991\end{array}$ & 3 & \\
\hline $\begin{array}{l}\text { One World } \\
\text { Trade Center }\end{array}$ & $\begin{array}{l}\text { New York } \\
\text { City }\end{array}$ & February 26, 1993 & 6 & $\begin{array}{c}\text { Bombing which also resulted } \\
\text { in } 1,042 \text { smoke related } \\
\text { injuries }\end{array}$ \\
\hline $\begin{array}{l}\text { Stratosphere } \\
\text { Tower }\end{array}$ & Las Vegas & August 30, 1993 & 0 & $\begin{array}{l}\text { Occurred during } \\
\text { construction }\end{array}$ \\
\hline $\begin{array}{l}\text { World Trade } \\
\text { Center } 1 \text { and } 2\end{array}$ & $\begin{array}{l}\text { New York } \\
\text { City }\end{array}$ & September 11, 2001 & 2312 & $\begin{array}{l}\text { Plane crash: September } 11 \\
\text { attacks. Full structural } \\
\text { collapse. }\end{array}$ \\
\hline 7 World Trade & New York & September 11, 2001 & 0 & $\begin{array}{l}\text { Debris coming from the } \\
\text { collapsing One World Trade }\end{array}$ \\
\hline
\end{tabular}




\begin{tabular}{|c|c|c|c|c|}
\hline Building & Location & Date & Death(s) & Notes \\
\hline Center & City & & & $\begin{array}{c}\text { Center: September 11 } \\
\text { attacks }\end{array}$ \\
\hline $\begin{array}{c}\text { Belaire } \\
\text { Apartments }\end{array}$ & $\begin{array}{c}\text { New York } \\
\text { City }\end{array}$ & October 11, 2006 & 2 & Plane crash \\
\hline $\begin{array}{c}\text { Deutsche } \\
\text { Bank Building }\end{array}$ & $\begin{array}{c}\text { New York } \\
\text { City }\end{array}$ & August 18, 2007 & 2 & $\begin{array}{c}\text { Oconstruction, demolished } \\
\text { due to damage from } \\
\text { the September 11 attacks }\end{array}$ \\
\hline $\begin{array}{c}\text { Casino } \\
\text { Las Vegas }\end{array}$ & January 25, 2008 & 0 & \begin{tabular}{c} 
Fire affecting top six floors \\
\hline
\end{tabular} \\
\hline
\end{tabular}

Japan: Japan Law of high rise building (Earthquake and fire)

Cite in Japan Law of high rise building. Japan experienced several building fire protection in 1629 Edo era, and was called Hikeshi. During the Meiji Period, when Japan opened its doors to the west, the Hikeshi was merged into the police department. Modern firefighting strategies were introduced in 1948, after World War II, a municipality fire service system was established. Today Japan is 894 fire headquarters and 3,598 volunteer fire corps. These have a total of 155,000 active career firefighters and 21,000 vehicles with 4,800 fire houses, 920,000 volunteer firefighters share an additional 51,000 trucks. Cited of "High Rise Building Fires" introduction High Rise Building Definition in Japan[3]. The Urban Building Law of Japan preceding the Building Standard Law of Japan regulated building heights below 20 min residential areas and below 31 min other areas as an Enforcement Order at the enactment of the legislation. Following the 1923 Great Kanto Earthquake, the notion that building height should be regulated became prevalent from the view of seismic safety, relating regulation to the Building Standard Law enacted in 1950. The height regulation was abolished when "The Building Standard Law" was revised in 1970 [4]. The31 m height corresponds to an 8-story building. Beginning in 2000 the Building Standard Law was revised to a performance-based structure with the prescriptive rules moved into the Building Standard Law Enforcement Order to facilitate updating and interpretation.

Korea: Korea government and NEMA research target on sub train fire and firefighter training simulation

Daegu metro fire accident change fire research part, NEMA research target on the subway smoke on the move. University of Korea and National Emergency Management Agency of Korea, research on simulation high rise building fire model. For the planning of "Tested Implementation of Training Simulator for Fire Fighting based on Tangible Technology”, overall analysis and validity review will be implemented of related systems, policies, technology and research trend, market and industry trend, and the trend of patents [5]. But in this simulation project not had multiply network training and computer graphic and physically part not enough good. 2012 NEMA R\&D research firefighter simulation fire based on game engine improve game graphic presence more reality. 
China: China researcher focus on High Rise Building, after JINMAO DASHA, CCTV Building fire accident

China government definition of high-rise building is stated in the Codes [7, 8]. Highrise buildings in Mainland China include those buildings having more than 10 stairs and those public buildings with a floor level higher than $24 \mathrm{~m}$ above ground level. They are further categorized into two types with respect to their usage, fire hazard class, means of escape and level of difficulty in firefighting and rescue [9].

Taiwan: Taiwan government research focus on "numerous building fires” thirty years

Numerous building fires caused considerable loss in human life and damage property. Table 3 discuss about Taiwan building fire list. Actual fires provide valuable information for fire protection research. Taiwan Fire researcher simulations can be used to effectively model of the fire and obtain useful and quantitative information to study the crucial fire dynamics characteristics based on FDS software [10].

Table 3. Recent Major Fires IN Military Dependents' Communities

\begin{tabular}{|c|c|c|}
\hline Date & Location & Casualties \\
\hline 2006.04 .09 & $\begin{array}{c}\text { Kongjun Village No. 8, Lane 136, } \\
\text { North Road, Hsinchu City }\end{array}$ & I dead \\
\hline 2007.07 .28 & An-Kon Village, Longtan, Taoyuan & 4 dead \\
\hline 2008.02 .24 & Yingju Village No. 7, Daliao, \\
Kaohsiung & $\begin{array}{c}2 \text { dead and I } \\
\text { seriously injured }\end{array}$ \\
\hline 2008.02 .13 & Heping East Road, Taipei City & $\begin{array}{c}\text { I dead and I } \\
\text { slightly injured }\end{array}$ \\
\hline
\end{tabular}

\section{Propose High Rise Building Model, Unity 3D Game Engine, FDS}

Fire Dynamics Simulator is a computational fluid dynamics (CFD) simulation model of fire-driven fluid flow. The software solves numerically a form of the Navier-Stokes equations, thermally-driven flow, with an emphasis on smoke and heat transport from fires. In install fire there has running file name's 'smokeview.exe' [16] is a visualization exe program that is used to display the output of FDS simulations result. The Fire Dynamics Simulator and result view applications are developed by the National Institute of Standards and Technology (NIST) of the US (United States American) Department of Commerce, in cooperation with VTT Technical Research Centre of Finland. And both FDS and Smoke view are free software for research and user using. In this paper using beta version FDS 6 and Smoke view version is 6.0.11 simulation High rise building [17].

Fire Dynamics Simulator (FDS) is a computational fluid dynamics model of fluid flow. The software based on Navier-Stokes equation which is suitable for low speed, thermally flow, smoke and heat simulation from fires. FDS is a free software by the NIST (National Institute of Standards and Technology of the USA Department of Commerce [24], VTT Technical Research Center of Finland. Execute "smokeview.exe”, load "example.smv", and visualization of fire. The "smokeview.exe" is a companion program that reads FDS's output of the excel file and produces animations on the user's screen. "smokeview.exe" has a simple menu-driven interface. Click the mouse right button and select the menu which shows only Smoke, HRR (Heat Release Rate) [25], Fire, or combines altogether.

\subsubsection{Material PVC, Cotton, Wood, and Leather Smoke Density}

Figure 1 image (a) and (b) shows material PVC size is $\mathrm{X}, \mathrm{Y}, \mathrm{Z}=0.5,0.5,0.5$ density is $1380 \mathrm{~kg} / \mathrm{m} 3$, emissivity is 0.95 , Absorption Coefficient $5.0 \mathrm{E} 41 / \mathrm{m}$. Concrete density is $2200.0 \mathrm{~kg} / \mathrm{m} 3$, specific heat $0.88 \mathrm{KJ} /(\mathrm{kg}-\mathrm{k})$, Conductivity $1.0 \mathrm{~W} /(\mathrm{m} . \mathrm{K})$, emissivity is 0.8 , Absorption coefficient 5.0E4 1/m. figure X shows Material PVC, Cotton, Wood, Leather 


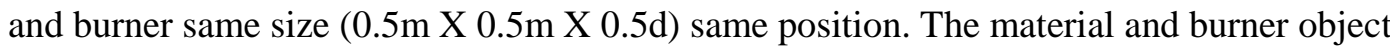
in same position of $3 \mathrm{D}$ space, object size is same.

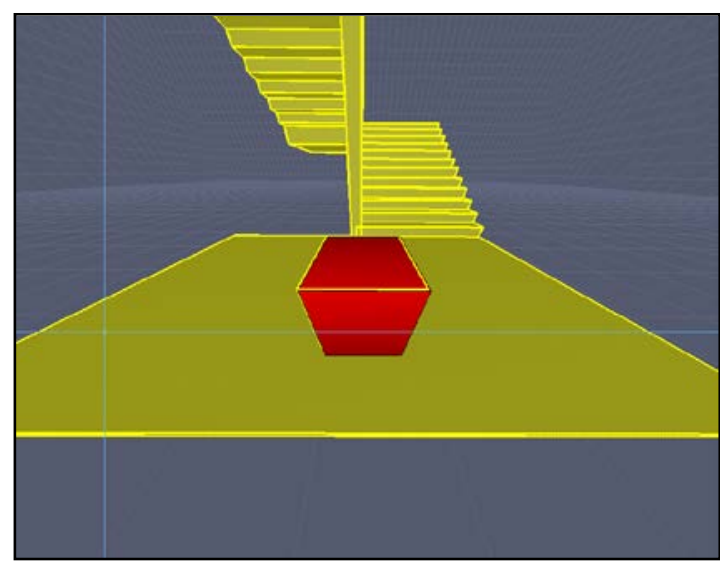

(a) Burner of High Rise Building object

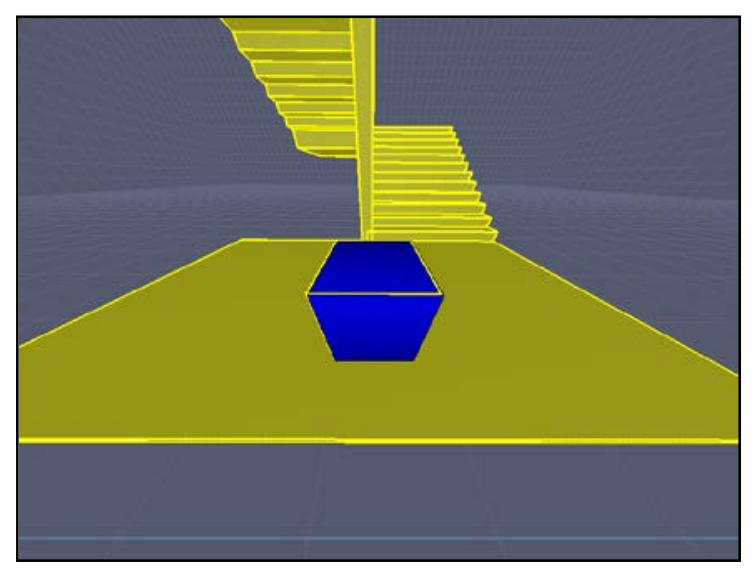

(b) Material of High Rise Building object

Figure 1. (a), (b) in Same Position Same Object Size, Material PVC, Cotton, Wood, Leather and Burner Same Size $(0.5 \mathrm{~m} \times 0.5 \mathrm{~m} \times 0.5 \mathrm{~m})$ Same Position

\subsubsection{High Rise Building Mesh Model}

High rise building $14^{\text {th }}$ floor $\mathrm{X}, \mathrm{Y}, \mathrm{Z}=60,60,120 \mathrm{~m}$ total of mesh cell is 432000 , total of model cell is 864000 . High rise boundary size is $X, Y, Z=18,1,57 \mathrm{~m}$. in this simulation help for vision change the outside boundary to invisible. Figure 2 shows high rise building model in FDS simulator. $1^{\text {st }}$ design high rise building to simulation need setting that concrete material of building body. Concrete material in global density is different, Korean's concrete density is $2000 \mathrm{~kg} / \mathrm{m}^{3}$ and didn't using value from FDS library Thermal Properties. And also Specific Heat is less than American so in simulation setting that value is $0.88 \mathrm{KJ} /(\mathrm{kg} . \mathrm{K})$, other value is same. Figure 2 shows high rise building mesh model result. Left one is show top of view, Right one show front of high rise building view. In this part using program c code to compute 1 stairs to X stairs. FDS file unname.fds it can using text type file system to open it. Support file system and programming to easy compute model coordinate position.

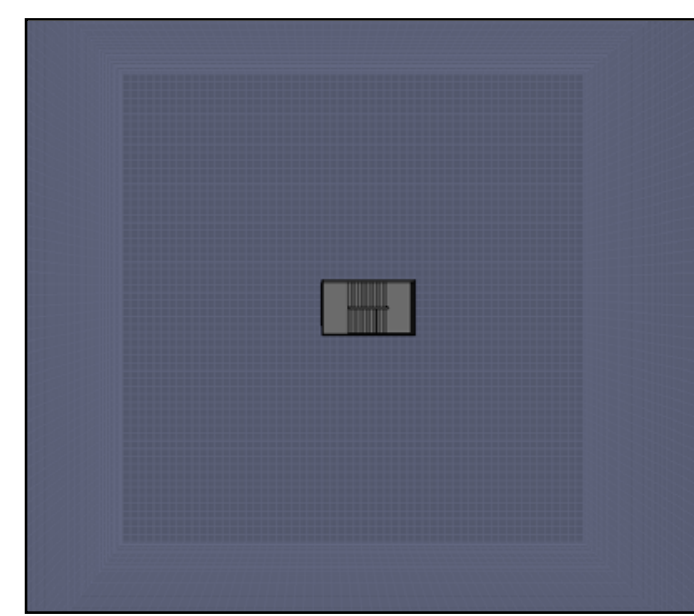

(a)High Rise Building model scene of top view

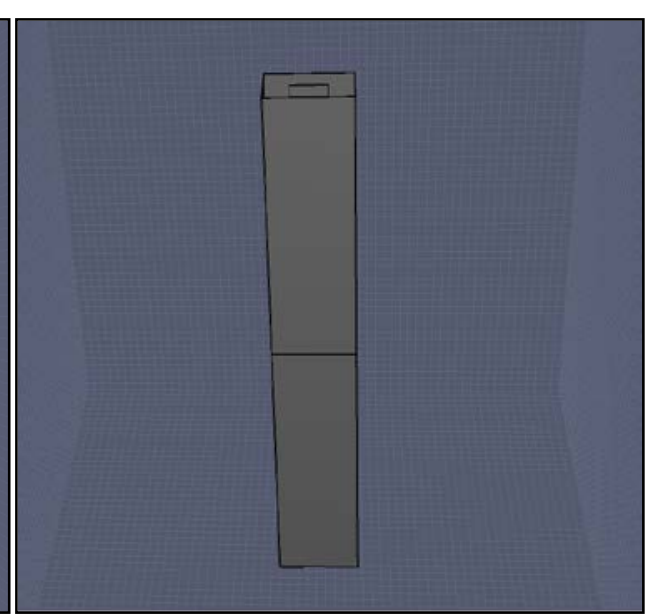

(b) High Rise Building model scene of front

Figure 2 (a), (b) 14 Stairs High Rise Building Mesh Model 


\subsubsection{High Rise Building Mesh Model}

In this section change outline high rise simulation model mesh to invisible and setting smoke detector to 3D space. Smoke detector [11] each position is X, Y, Z $=0.5 \mathrm{X} 0.5 \mathrm{X}$ $0.5 \mathrm{~m}$ all smoke detector is $2052+$ out line upper part 500 total is 2552 sensor in space. Acutely there are not needs too many sensors in space like this simulation. But in Unity $3 \mathrm{D}$ game engine particle model change different common one. The algorithm to game engine control it each space in $0.5 \mathrm{X} 0.5 \mathrm{X} 0.5 \mathrm{~m}$. It reduce complex part to easy impalement it game scene. Figure 3 (a), (b) shows after compute high rise building mesh coordinate model to invisible mode. Figure 4 (a), (b) shows after invisible mode high rise building model in mesh [14].

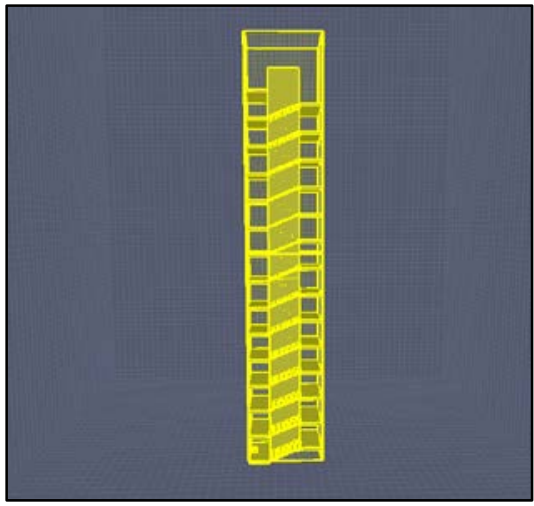

(a) Invisible high rise building front

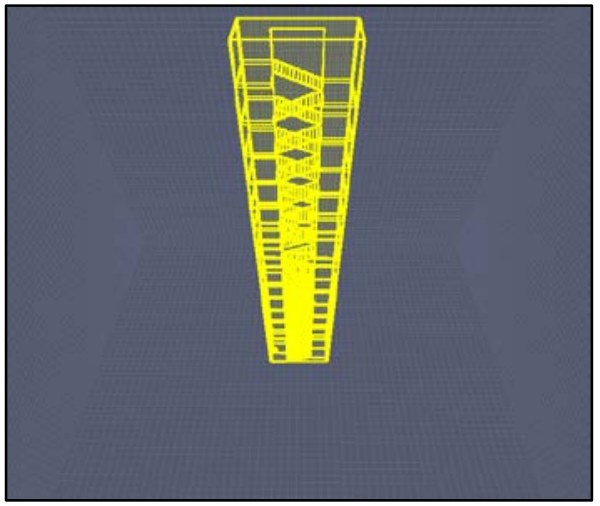

(b) Invisible high rise building in top

Figure 3. Invisible High Rise Building Mesh Model
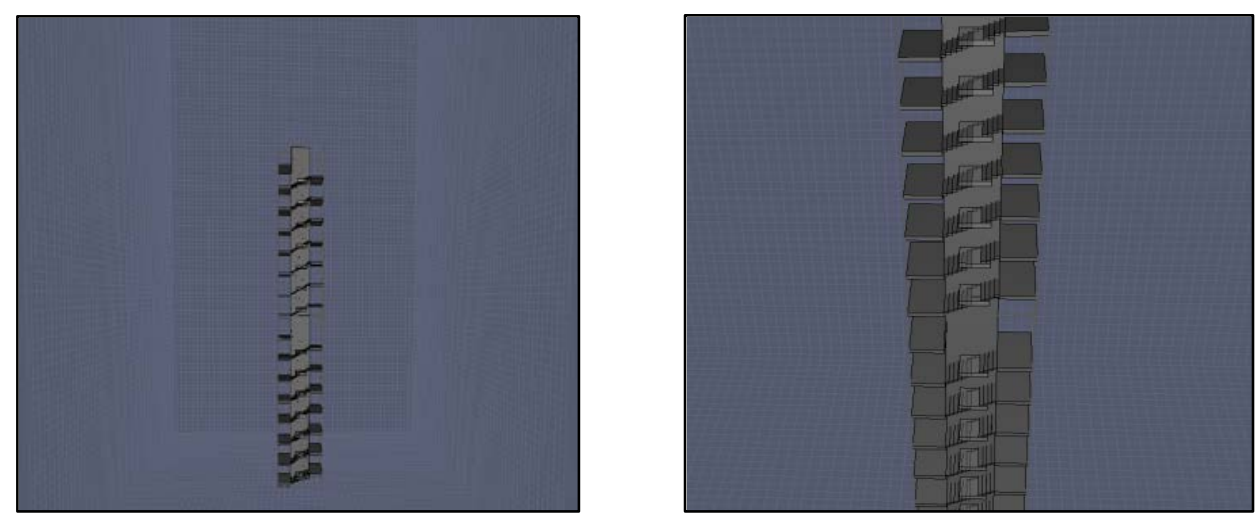

(a) After invisible high rise building front (b) After invisible high rise building in top

\section{Figure 4. After Invisible High Rise Building Mesh Model}

\subsubsection{High Rise Building Mesh Model Stair}

Figure 5 shows High Rise Building Stair model. There 1 floor has 12 X 2 stair cases, 1floor has 1 dumbwaiter shafts. All models has 336 stairs and 14 dumbwaiter shafts. The material and burner in 1 floor simulation is start $1 \mathrm{~s}$ to $2500 \mathrm{~s}$, smoke and heat start in $1 \mathrm{~s}$. Figure 6 shows simulation at 1s times. In that picture material PVC has start burning. But in view FDS Simulation mix some detail part to burring. From FDS shows stairs mix view. 


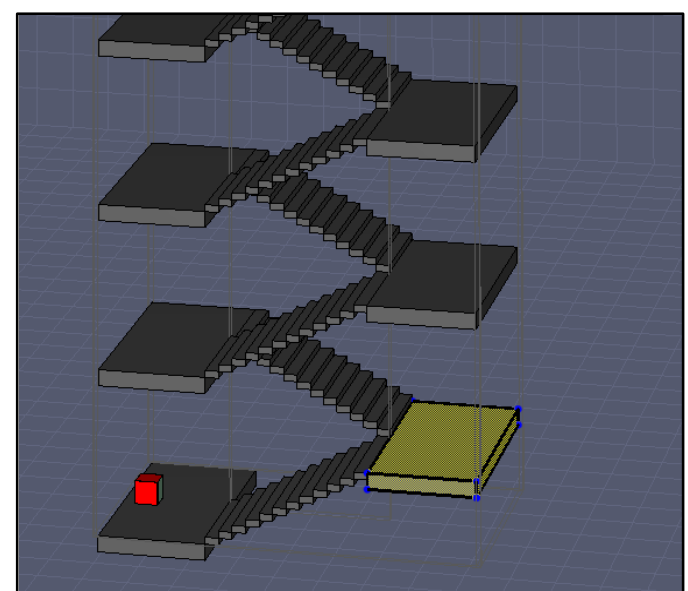

(a) High Rise Building Stair Model Dumbwaiter Shafts

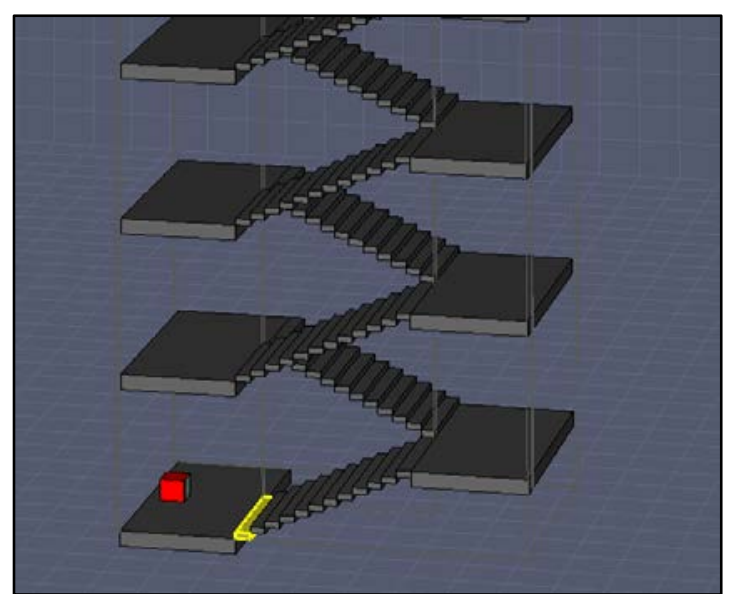

(b) High Rise Building Stair Case

Figure 5. After Invisible High Rise Building Mesh Model

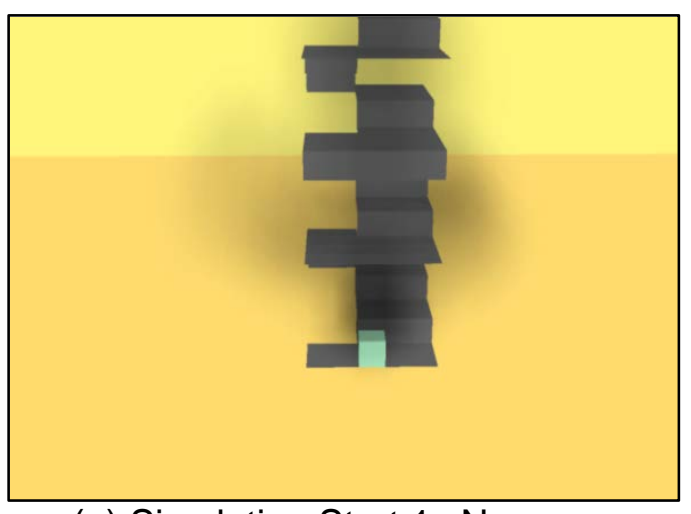

(a) Simulation Start 1s Near Distance View

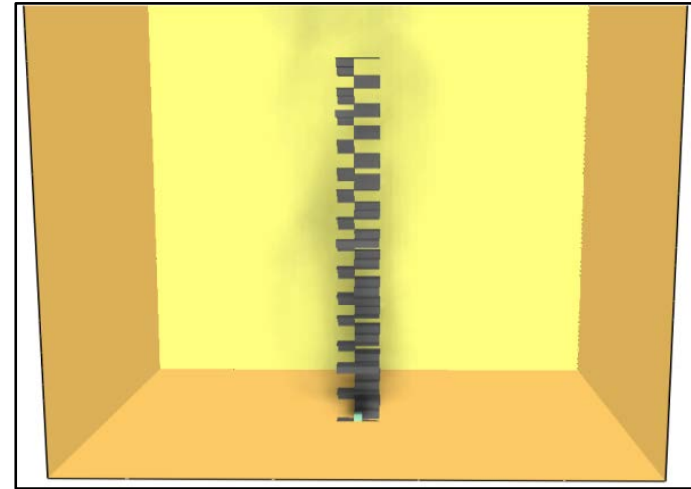

(b) Simulation Start 1s Long Far Distance View

Figure 6. Simulation Start 1s Start View

\subsection{FDS Simulation Environment}

Simulation time is 2000 second. High rise building $14^{\text {th }}$ floor $X, Y, Z=60,60,120 \mathrm{~m}$ total of mesh cell is 432000 , total of model cell is 864000 . High rise boundary size is $X, Y$, $\mathrm{Z}=18,1,57 \mathrm{~m}$. in this simulation total is 5 days 4hour, in scene so many sensor delay the computing time. Simulation computer i5, NVIDIA 650gtx, memory 8Gb, Win7 64bit, option is OpenMP support multicore hardware.

\section{Limitations}

In this paper simulation $14^{\text {th }}$ floor need too many computing time and FDS also skip stair object to simple. The result sensor data frequency is too hard finding about function to simple it. From function frequency (sampling data) also need to times. The High Rise Building environment change a little part need change air, building model, material, that means need simulation once more. Need find more efficient powerful function reduce these limitations.

\section{Conclusions and Future Work}

Previous section part we discuss high rise building model used game engine simulation and imp element. Fire model of stack effect is different common fire model also different 
other fire model. It had fast heat temperature grow up because fire had more oxygen gas; the reason high rise building makes it. Unity game engine part based on paper [12] to simulation it. At last we add oxygen gas part. We know if using like FDS simulation research navior-stoker algorithm or physically algorithm is very hard to simulation it. Oxygen gas part change physically to simple function it is means that code near reality coordinate but cannot mean that coordinate is truth. And all the programming simulation based on FDS, but FDS result also have some part need improve. Future work need find about FDS improve part and find about reality coordinate.

\section{Acknowledgement}

This paper was Researched (2012) The Next Generation Fire protection \& Safety Core Technology Development program of National Emergency Management Agency (NEMA) of Republic Korea.

\section{References}

[1] P. M. Adeley and F. Jiang, "Passive and active protection of high rise buildings", Journal of Anhui Institute of architecture, vol. 7, no. 3, (1999).

[2] J. R. Hall, Jr., "High-Rise Building Fires", National Fire Protection Association Fire Analysis and Research Division, (2011) December.

[3] M. Kohno, "High-Rise Building Fires”, Journal of Disaster Research, vol. 2, no. 4, (2007), pp. 236-249.

[4] R. W. Bukowski, "Emergency Egress from Building Part 1: History and Current Regulations for Egress Systems Design”, New Zealand, Society of Fire Protection Engineers, Bethesda, MD, (2008), pp. 167191.

[5] Yoonhoseo, "A Planning Study on Testbed Implementation of Training Simulator for Fire Fighting based on Tangible Technology”, NEMA-2010 Project Report, (2010).

[6] M. Daniel and K. Stephen, "Fire Fighting Tactics Under Wind Driven Conditions: Laboratory Experiments", NIST Technical Note 1618, (2009) January.

[7] GBJ 45-82, Code for Fire Protection Design Tall Buildings, National Standard of The People's Republic of China, in Chinese, (1983).

[8] H. Ma, "Illustrative description to the GB50045-95", Code for Fire Protection Design Tall Buildings, Public Co. China, in Chinese, (1995).

[9] W. Y. Hung and W. K. Chow, "Review on Fire Regulations for new High-Rise Commercial Buildings in Hong Kong and a Brief Comparison with those in Overseas”, International Journal on Engineering Performance-Based Fire Codes, vol. 3, no. 1, (2001), pp. 25-51.

[10] L. Chemg-Shing, C. Te-Chi and W. Shih-Cheng, "Computer Modeling and Simulation of a Townhouse Fire Dynamic Field Characteristics”, IEEE Symposium on Electrical \& Electronics Engineering (EEESYM), (2012).

[11] X. Yongzhe, K. Lee, E. Kim, J. Ki and B. Lee, "Simulation of Smoke to Improve Unity 3D Game Engine Particle System based on FDS”, SofTech, (2013).

[12] Unity Team. Unity Manual. Particle System, positioning Game Objects.

[13] M. G. Good, "Fire Protection of Structural Steel in High-Rise Buildings”, NIST GCR 04-872, (2004).

[14] J.-H. Shin, S.-M. Lee and D.-J. Kim, "An Analysis in the Correlation between Frontal Lobes/Occipital Lobes Parts' Neural Waves in Case of 3D Syndrome Outbreak While Watching 3D Object", International Journal of Multimedia and Ubiquitous Engineering, vol. 7, no. 2, (2012) April.

[15] M. Kevin, K. Bryan, H. Simo and F. Jason, "Fire Dynamics Simulator (version 5)", NIST Special Publication 1019-5. NIST.

[16] G. P. Forney, "User's Guide for Smokeview Version 5-A Tool for Visualizing Fire Dynamics Simulation Data”, NIST Special Publication 1017-1 CODEN:NSPUE2, Fire Research Division Building and Fire Research Laboratory, (2007) August.

[17] W. Magnus, F. Henrik, A. Chris and M. Stephen, "Capturing Thin Features in Smoke Simulations", Siggraph Talk 2011.

[18] G. Hadjisophocleous and Y. J. Ko, "Using a CFD Simulation in Designing a Smoke Management System in a Building”, Winter Simulation Conference, (2006).

[19] G. Rein, X. Zhang, P. Williams, B. Hume, A. Heise, A. Jowsey, B. Lane and J. L. Torero, "Multi-Storey Fire Analysis for High-Rise Buildings”, $11^{\text {th }}$ Interflam 2007 London, (2007). 


\section{Authors}

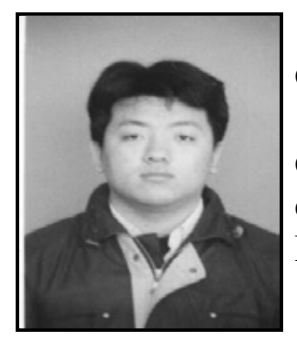

Yongzhe $\mathrm{Xu}$ received his MS in Computer science and engineering from Univesity of Incheon, Korea, in 2009.

$\mathrm{He}$ is currently working toward a $\mathrm{PhD}$ in computer science and engineering at the same university. His research interests include computer graphic, FDS, virtualization, and Pattern Recognization, Machine Learning.

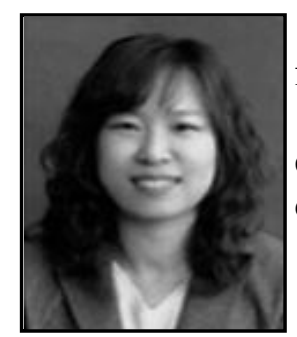

Eunju Kim received her MS in computer science and engineering from University of Incheon, Korea, in 2010.

She is currently working toward a $\mathrm{PhD}$ in computer science and engineering at the same university. Her research interests include computer vision, image processing, and Artificial intelligence.

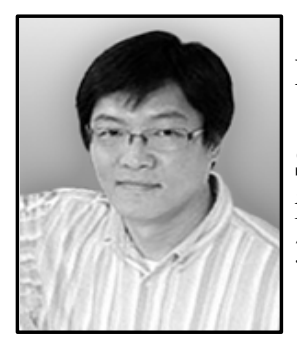

Kyunjoo Lee received his bachelor's degree in Department of Philosophy from korea university in 1991, 1993-1999 和像音 CEO, 1999-2001 Oz Intern Media project chief, 2001-2002 Muhon virtual Society Game team leader, 2002-2013 MaxonSoft CTO. His interesting about multi-platform game, fire protection training game, 3D Game engine

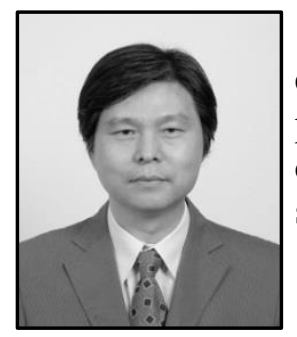

Jaesug Ki received his doctor of Department of industrial engineering from HanYang university in 1993.1993-2000 associate professor in Kangwon National University. 2000-2006 a laboratory chief in KCI. His interesting about fire protection training simulation, sports training simulation, National Defense weapon simulation

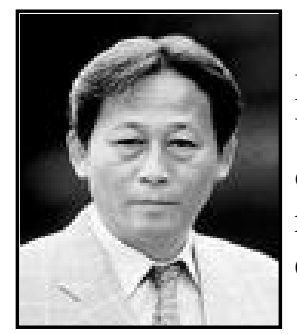

Byungsoo Lee received his MS in MBA from University of Dongguk, Korea, 1980. Received his Doctor of Science from University of KyongGi, Korea, 1998 He is a Professor of Department of Computer Engineering at the University of Incheon, Korea. His research interests include software design, decision making system, eCRM, RFID/USN, IT convergence 